\title{
Physicochemical Properties And Sensory Evaluation Of Fermented Mustard With Difference Ratio Of Rice Water And Tal Palm Sap
}

\author{
Author \\ Nur Agustin Mardiana (Orcid ID. 0000-0003-2013-3225) \\ Domas Patria Galih (Orcid ID. 0000-0002-1280-8985) \\ Sutrisno Adi Prayitno (Orcid ID. 0000-0002-5116-166X) \\ Chusnul Chotimah (OrcidID. 0000-0003-2595-5738)
}

\author{
Correspondence \\ Department of Food Technology, Faculty of Agriculture, Universitas Muhammadiyah Gresik \\ Nuragustin@umg.ac.id
}

\begin{abstract}
:
Tal palm plant is widely known and spread in Indonesia. However, the application of tal palm plant especially sap as another product is limited. Tal plant sap used in mustard fermentation as carbon source with rice water. The aim of this study is to find suitable ratio of rice water and tal palm sap for the best physicochemical properties and sensory characteristic of fermented mustard. This experiment was using completely randomized design with one factor and 5 treatment groups. The evaluation of physichochemical performed to measure total acidity, polyphenol, and flavonoid. The sensory evaluation was using hedonic test with untrained panelists and determine score for parameters such as color, aroma, texture, and taste. The results showed that the highest total acidity was 1,06\% which found in sample with ratio of rice water and tal palm sap (0:1). However the highest total polyphenol was 15,87 (mg GAE/g) and total flavonoid was $4,52(\mathrm{mg} \mathrm{QE} / \mathrm{g})$ found when the ratio of rice water and tal palm sap similar (1:1). Based on the sensory evaluation, sample with ratio of rice water and tal palm sap (3:1) has the highest score on color was 3,17 ; aroma was 3,00; and taste was 3,00. Accordingly, this study provide data to enhance economical value and product development for tal palm sap.
\end{abstract}

Keywords: Fermented Mustard, Phytochemical, Sensory, Tal Palm Sap, Rice Water

Received: 28 July 2021. Accepted: 21 December 2021.

\section{Introduction}

Tal palm plant (Borassus flabellifer) grows and spreads in several areas in Indonesia. According to Muhammad \& Elna (2008), the plantation of tal palm tree in Central Java, East Java, and Madura reaches 15,000 ha with a total plants of around 500,000. Tal palm plant is usually cultivated and utilized by community, one part of the tree that can be utilized is the sap. Nira from tal palm is usually only sold as legen water or as raw material for making tal palm sugar (Kirana et al., 2016). The use of tal palm sap as another product has not been widely known, including being used in the production of fermented mustard.

Fermented mustard are widely known in Indonesia as source of vitamin A, K, and phenolic and flavonoid compound. Kamdee et al. (2014) report that fermented mustard exhibit high antioxidant activity due to bioactive component which produce during fermentation.

Another study by Eun-Jeong et al. (2005) state that it has anticancer activity, cytotoxic activity, and prevent hypertensive.

Indigenous bacteria which involved in mustard fermentatin has been identified. Most of them are homofermentative and heterofermentative lactic acid bacteria. The existence of homofermentative and hetero fermentative lactic acid bacteriala will plays important role in production unique bioactive compounds which contribute to health effect and sensory characteristics. However growth of bacteria depends on the availability of nutrition especially carbon source (Fransisca et al., 2000).

Traditionally, rice water will be added as carbon source in mustard fermentation. However, there is no information about addition of another carbon source in fermented mustard such tal palm 
sap. According to Klau \& Ngginak. J (2019), tal palm sap has high sugar content. Thus the addition of tal palm sap is expected to improve psychochemical and sensory properties of fermented mustard.

The purpose of this study was to find suitable ratio of tal palm sap with rice water in the production of fermented mustard based on physicochemical properties and sensory evaluation such as texture, aroma,taste, and color.

\section{Materials and Method}

Materials used in this experiments are leaf mustard, salt, rice, and tal palm sap.

Chemical and reagent used in this experiments are $\mathrm{NaOH}$, indicator $\mathrm{PP}, \mathrm{Na}_{2} \mathrm{CO}_{3}$, Folin Ciocalteu, aquadest, ethanol 95\%, $\mathrm{NaNO}_{2}$, and $\mathrm{AlCl}_{3}$,

Tools used in this experiments are flask, tube, beaker glass, Spectrophotometer Visible (Spectro 20 D Plus), vortex, measuring pipet, pipet filler, analytical balance, and spatula.

\section{Preparation of Fermented Mustard (Fransisca et al., 2000)}

Mustard was sortated, and washed with clean water. 100 gram of mustard put into clean basket and mixed with $3 \%$ of salt (w/w). Put the mixture into plastic jar and added the difference variation of ratio between rice water and tal palm sap. Fermented for 3 days.

\section{Total Acidity Assay (Aristya et al., 2013)}

$10 \mathrm{ml}$ of sample put into $250 \mathrm{ml}$ flask. Added $2 \mathrm{ml}$ of indicator PP and titrate with $\mathrm{NaOH}$ $1 \mathrm{~N}$ until the color changed into pink and measured the total acidity of each samples.

\section{Total Polyphenol Assay (Fadillah et al., 2017)}

5 grams of sample was put into test tube, added 2,5 $\mathrm{ml}$ of ethanol $95 \%$ and mixed with vortex for 10 minutes. Take $1 \mathrm{ml}$ of sample and put into another tube and added $4 \mathrm{ml}$ of aquadest, $1 \mathrm{ml}$ of ethanol 95\%, and 2,5 $\mathrm{ml}$ Folin Ciocalteu. The mixture was allowed to stand for 5 minutes and added $1 \mathrm{ml} \mathrm{Na} \mathrm{CO}_{3}$ and mixed. After that, allowed to stand for 30 minutes and measured the absorbance values at $\kappa 760 \mathrm{~nm}$.

\section{Total Flavonoid Assay (Fadillah et al., 2017)}

5 grams of sample was put into test tube, added $4 \mathrm{ml}$ of aquadest, and 0,3 $\mathrm{ml} \mathrm{NaNO} 2$. Allowed to stand for 6 minutes. After that, added $0,3 \mathrm{ml} \mathrm{AlCl} 310 \%$ and allowed to stand for 15 minutes. Measured the absorbance values at $K 510$ nm.

\section{Sensory Evaluation (Prayitno et al., 2021)}

Sensory evaluation was using hedonic test with 10 untrained panelists. The hedonic test was using scale namely $1=$ dislike very much, $2=$ dislike, 3= like, 4= like slightly, 5= like very much. Parameter in sensory evaluation is taste, color, aroma, and texture.

\section{Design of Experiment}

This experiment was using completely randomized design with one factor. The experiments was using 5 treatment groups with each groups having different variation of ratio between rice water and tal palm sap which are seen in Table 1 . The result of experiment was analyzed with Minitab 17. The significant difference among the data were evaluated using One Way Anova followed by Fisher test $(p<0,05)$.

Table 1. Variation of Ratio Between Rice Water and Tal Palm Sap

\begin{tabular}{ll}
\hline Sample Code & $\begin{array}{l}\text { Ratio Rice Water: Tal Palm } \\
\text { Sap }\end{array}$ \\
\hline T1 & $0: 1$ \\
T2 & $1: 3$ \\
T3 & $1: 1$ \\
T4 & $3: 1$ \\
T5 & $1: 0$ \\
\hline
\end{tabular}

\section{Results and Discussion \\ Total Acidity}

Total acidity showed lactic acid bacteria activity which breakdown lactose into lactic acid during fermentation process. The result of total acidity from difference ratio between rice water and tal palm sap ranged from $0,30 \%$ to $1,06 \%$ which shown in Table 2. 
Tabel 2. Total Acidity of Fermented Mustard After 3 Days Fermentation

\begin{tabular}{ll}
\hline Sample Code & Total acidity $(\%)$ \\
\hline T1 & $1,06^{\mathrm{a}}$ \\
T2 & $0,84^{\mathrm{b}}$ \\
T3 & $0,73^{\mathrm{c}}$ \\
T4 & $0,49^{\mathrm{d}}$ \\
T5 & $0,30^{\mathrm{e}}$ \\
\hline
\end{tabular}

Means with different letters in the same colomn are significantly different based on Fisher test $(\mathrm{P}<0,05)$.

Table 2 showed that treatment of ratio between rice water and tal palm sap has a significant different on the total acidity of fermented mustard $(\mathrm{p}<0.05)$, with the highest value of total acidity is $1,06 \%$ which is from sample $\mathrm{T} 1$ or the ratio of rice water and tal palm sap $(0: 1)$. This result showed that total acidity of fermented mustard increased with higher concentration of tal palm sap. The increase in total acidity was in line with the increase in the ratio of tal palm sap which used in making fermented mustard. According to Silaban (2017), Tal palm sap contain $154 \mathrm{~g} / \mathrm{L}$ glucose, $199 \mathrm{~g} / \mathrm{L}$ fructose, and $105 \mathrm{~g} / \mathrm{L}$ sucrose. The high sugar level in tal palm sap is used by lactic acid bacteria to break down sugar into lactic acid so the acidity will increase (Mubin \& Zubaidah, 2016).

\section{Total Polyphenol and Total Flavonoid}

The result of total polyphenol from difference ratio between rice water and tal palm sap ranged from 9,87 to $15,87 \mathrm{mg} \mathrm{GAE} / \mathrm{g}$. Whereas the result of total flavonoid from difference ratio between rice water and tal palm sap ranged from 1,12 to $4,52 \mathrm{mg}$ QE/g. All of the results are presented in Table 3 .

Tabel 3. Total Polyphenol and Flavonoid of Fermented Mustard After 3 Days Fermentation

\begin{tabular}{lll}
\hline $\begin{array}{l}\text { Sample } \\
\text { Code }\end{array}$ & $\begin{array}{l}\text { Total polyphenol } \\
(\mathbf{m g ~ G A E} / \mathbf{g})\end{array}$ & $\begin{array}{l}\text { Total flavonoid } \\
(\mathbf{m g ~ Q E} / \mathbf{g})\end{array}$ \\
\hline T1 & $12,43^{\mathrm{c}}$ & $2,16^{\mathrm{c}}$ \\
$\mathrm{T} 2$ & $11,39^{\mathrm{d}}$ & $2,44^{\mathrm{b}}$ \\
T3 & $15,87^{\mathrm{a}}$ & $4,52^{\mathrm{a}}$ \\
T4 & $14,98^{\mathrm{b}}$ & $1,65^{\mathrm{d}}$ \\
T5 & $9,87^{\mathrm{e}}$ & $1,12^{\mathrm{e}}$ \\
\hline
\end{tabular}

Means with different letters in the same colomn are significantly different based on Fisher test $(\mathrm{P}<0,05)$.

Table 3 showed that treatment of ratio between rice water and tal palm sap has a significant different on the total polyphenol of fermented mustard $(\mathrm{p}<0.05)$. This result showed that different treatments produced different total polyphenol between samples, with the highest total polyphenol is $15,87(\mathrm{mg} \mathrm{GAE} / \mathrm{g})$ which is from sample $\mathrm{T} 3$ or the ratio of rice water and tal palm sap (1:1). This was probably correlated with activity of lactic acid bacteria during fermentation which optimum in producing the highest polyphenol when the ratio of rice water and tal palm sap is similar.

Lactic acid bacteria have important role in fermentation of mustard. The growth of lactic acid bacteria is influence by some factors, one of them is sugar sources. Lactic acid bacteria utilize sugar for bacteria growth. In this study, each treatment might have different sugar content so it will influence bacterial activity. According to Muscariello et al. (2001), different sugar sources can induce or repress enzyme activity of lactic acid bacteria even though the mechanism remains unknown. Added by Kamdee et al. (2014), the higher values of total polyphenol in fermentation due to metabolic activities during the growth of cell, which decomposed large molecules into small phenolics. Lactic acid bacteria have enzymes such as tannase, pcoumaric acid decarboxylase (PAD), and benzyl alcohol dehydrogenase which can degrade some phenolic compounds (Rodríguez et al., 2009).

Meanwhile, total flavonoid with different ratio between rice water and tal palm sap also showed significant different $(\mathrm{p}<0.05)$. This result showed that different treatments produced different total flavonoid between samples. Total flavonoid of fermented mustard showed similar tendency as total polyphenol with the highest total flavonoid is $4,52(\mathrm{mg} \mathrm{GAE} / \mathrm{g})$ which is also from sample $\mathrm{T} 3$ or the ratio of rice water and tal palm sap (1:1). This study confirms the observation carried out by Jakubczyk et al. (2020), various carbon source produce different type of metabolites which influence of polyphenol, flavonoid, and organic acids content during fermentation.

During fermentation, numerous reactions occur that effect flavonoid content. According to Kwak et al. (2018), total flavonoid might be increase due to the conversion of insoluble phenolic compounds into soluble flavonoids. 
This is in agreement with the observations of other investigator that fermentation process could enhance release of some polyphenolic compounds (Adetuyi \& Ibrahim, 2014). As reported by Makarewicz et al. (2021), flavonoid is part of polyphenols group which produced secondary metabolites using secondary pathway.

\section{Sensory Evaluation}

During fermentation, lactic acid bacteria produce some secondary metabolites such as organic acid which influence mustard characteristic. In this study to measure acceptance level of fermented mustard, we used hedonic test with untrained panelists. The untrained panelist was asked to rate the parameter of fermented mustard for each treatment groups using score from 1 until 5 . The result of sensory evaluation was shown in Table 4.

Tabel 4. Result of Sensory Evaluation

\begin{tabular}{lllll}
\hline Sample & Color & Aroma & Texture & Taste \\
\hline T1 & $3,00^{\mathrm{a}}$ & $1,83^{\mathrm{b}}$ & $3,17^{\mathrm{b}}$ & $1,67^{\mathrm{b}}$ \\
$\mathrm{T} 2$ & $2,67^{\mathrm{a}}$ & $2,17^{\mathrm{ab}}$ & $2,67^{\mathrm{b}}$ & $2,17^{\mathrm{ab}}$ \\
$\mathrm{T} 3$ & $2,83^{\mathrm{a}}$ & $2,17^{\mathrm{ab}}$ & $3,17^{\mathrm{b}}$ & $2,67^{\mathrm{ab}}$ \\
$\mathrm{T} 4$ & $3,17^{\mathrm{a}}$ & $3,00^{\mathrm{a}}$ & $3,00^{\mathrm{b}}$ & $3,17^{\mathrm{a}}$ \\
$\mathrm{T} 5$ & $3,17^{\mathrm{a}}$ & $2,83^{\mathrm{ab}}$ & $3,83^{\mathrm{a}}$ & $2,83^{\mathrm{a}}$ \\
\hline
\end{tabular}

Means with different letters in the same colomn are significantly different based on Fisher test $(\mathrm{P}<0,05)$.

\section{a. Color}

Color is important parameter that determine the quality of food. According to Capule \& Barcelon (2014), color is major factor in making decision to accept or reject food without tasting the food itself. Color is the first sensory parameter that influence costumer's perspective and as well as others sensory parameter such as taste, aroma, and flavor of food.

Based on the Table 4, the highest acceptance score for color parameter found in sample T1 $(0: 1)$ and T5 (1:0) but it is not significant different compare to sample T2 (1:3), T3 (1:1) and T4 (3:1). This might be happened due to panelists find it difficult to distinguish the color between each treatment. Each treatment has similar appearance in color which is yellowish green.

Mustard leaf contain chlorophyll as pigment and during fermentation process chlorophyll would be degraded (Santra et al., 2021). Added by Roca \& Mínguez-Mosquera (2001), fermentation process produces organic acid and increase the acidity of product. Increase in acidity would help protons to replace the magnesium ion centered at the porphyrin ring and chlorophylls would convert into pheophytins. That process will change the color of pigment from green to yellow.

\section{b. Aroma}

From Table 4, the highest acceptance score for aroma parameter found in sample T4 (3:1). It is significantly different compared to T2 (1:3), T3 (1:1), and T4 (3:1), but it is significantly different compared to T1 $(0: 1)$. Panelists find that the aroma of fermented mustard added with tal palm sap is quite strong. It might be happened due to natural aroma of tal palm which is strong and lactic acid bacteria activity during fermentation process which produce volatile compounds that contributes to aroma of fermented mustard.

As reported by Behera et al. (2020), lactic acid bacteria can produce volatile components such as alcohols, aldehydes, ketones, fatty acids, esters, sulfur compounds, and organic acids. As reported by Smid \& Kleerebezem (2014), the formation of aroma depend on activities of various enzymes that are mostly secreted in the food matrix by the fermenting microbes and complete metabolic pathways present in intact and metabolically active microbial cells.

\section{c. Texture}

Based on Table 4, the highest acceptance score for texture parameter found in sample T5 (1:0). It is significantly different compared to $\mathrm{T} 1$ (0:1), T2 (1:3), T3 (1:1), and T4 (3:1). This might be happened because lactic acid bacteria has abundant enzyme that related with texture change of fermented mustard. As reported by Maruvada \& McFeeters (2009), softening texture that occurs during fermentation due to polygalacturonates enzyme which is produced by bacteria. Polygalacturonase can degrade cell wall polysacharides in mustard and change firmness of mustard texture into soft. 


\section{d. Taste}

Taste determines food acceptability which are detected by receptors on tounge. The reseptors will determine basic taste such as sweet, salt, bitter, sour, umami and olegustus (Barylko-Pikielna et al., 2004).

Based on Table 4, the highest acceptance score for taste parameter found in sample $\mathrm{T} 4$ (3:1). It is not significantly different compared to T2 (1:3), T3 (1:1), and T5 (1:0), except for T1 $(0: 1)$. This might be happened due to panelists find it difficult to distinguish the taste between each groups except for sample T1. Panelist prefers fermented mustard with low ratio of tal palm sap. In sample T1, the carbon sources which used is only tal palm sap and it might be due to higher sugar content in fermentation process bacteria produced higher acidity. Hence it influence the acceptability of fermented mustard.

According to McFeeters (2004), changes in taste during fermentation occur because of the interaction between active enzyme from the raw material with metabolic activities of microorganism. Complex metabolism pathway during fermentation would produce taste diversity between the products. This is supported by Zhao et al. (2016) observation that showed amino acids, amino acid derivatives and active peptides found in fermented food related with taste which produce during fermentation.

\section{Conclusion}

From the results of study, we can conclude that based on sensory evaluation, panelist prefers only rice water as media for mustard fermentation. However, the treatment group which has similar ratio between tal palm sap and rice water was giving the best psychochemical properties compared to others treatments.

\section{References}

Adetuyi, F. O., \& Ibrahim, T. A. 2014. Effect of Fermentation Time on the Phenolic, Flavonoid and Vitamin $C$ Contents and Antioxidant Activities of Okra (Abelmoschus esculentus) Seeds. Nigerian Food Journal, 32(2),128-137.

Aristya, A., Legowo, A., \& Al-Baarri, A. 2013. Total Asam, Total Yeast, Dan Profil Protein
Kefir Susu Kambing Dengan Penambahan Jenis Dan Konsentrasi Gula Yang Berbeda. Jurnal Pangan Dan Gizi, 4(7), 116426. https://doi.org/10.26714/jpg.4.1.2013.

Barylko-Pikielna, N., Matuszewska, I., Jeruszka, M., Kozlowska, K., Brzozowska, A., \& Roszkowski, W. 2004. Discriminability and appropriateness of category scaling versus ranking methods to study sensory preferences in elderly. Food Quality and Preference, 15(2), 167-175. https://doi.org/10.1016/S0950-

3293(03)00055-7

Behera, S. S., El Sheikha, A. F., Hammami, R., \& Kumar, A. 2020. Traditionally fermented pickles: How the microbial diversity associated with their nutritional and health benefits. Journal of Functional Foods, 70(April), 103971 https://doi.org/10.1016/j.jff.2020.103971

Capule, A. B., \& Barcelon, E. G. 2014. Influence of Colour on the Sensory Perception of Ready-To- Influence of Colour on the Sensory Perception of Ready-To-Drink Soy Milk. Asian Journal of Science and Technology, 5(12), 879-882.

Eun-Jeong, Y., Hyun-Soo, L., Kyung-Ok, P., \& Myeong-Rak, C. 2005. Cytotoxic, antioxidative and ACE inhibiting activities of Dolsan leaf mustard juice (DLMJ) treated with lactic acid bacteria. Biotechnology and Bioprocess Engineering, 10(1), 60-66.

F, K. H., \& Ngginak. J, N. T. S. 2019. Kandungan Gula Reduksi Dalam Nira Siwalan (Borassus flabellifer L) Sebelum Pemasakan dan setelah Proses Pemasakan. BIOSFER, J.Bio. \& Pend.Bio, 4(1), 19-24.

Fadillah, A., Rahmadani, A., \& Rijai, L. 2017. Analisis Kadar Total Flavonoid Dan Uji Aktivitas Antioksidan Ekstrak Daun Kelubut (Passiflora foetida L.). Proceeding of the 5th Mulawarman Pharmaceuticals Conferences, 1(1) 
Fransisca, I., Nugerahani, I., Indarto, T., \& Suseno, P. 2000. Pengaruh Perbandingan Air dan Beras pada Pembuatan Air Tajin terhadap Sifat Fisikokimia dan Organoleptik Sayur Asin. Jurnal Teknologi Pangan Dan Gizi, 1(2).

Jakubczyk, K., Kałduńska, J., Kochman, J., \& Janda, K. 2020. Chemical profile and antioxidant activity of the kombucha beverage derived from white, green, black and red tea. Antioxidants, 9(5). https://doi.org/10.3390/antiox9050447

Kamdee, S., Plengvidhya, V., \& Chokesajjawatee, N. 2014. Changes in lactic acid bacteria diversity during fermentation of sour pickled mustard green. 26-33.

Kirana, C., Hastuti, U. S., \& Suarsini, E. 2016. Kajian Kualitas Nata de Nira Siwalan (Borassus Flabelliver L) dengan Variasi Macam Gula dalam Beberapa Konsentrasi sebagai Materi Handout Biologi Kelas XII MAN Pamekasan. Proceeding Biology Education Conference, 13(1), 178-186. https://jurnal.uns.ac.id/prosbi/article/viewFi le/5688/5056

Kwak, H. S., Jeong, Y., \& Kim, M. 2018. Effect of Yeast Fermentation of Green Coffee Beans on Antioxidant Activity and Consumer Acceptability. Journal of Food Quality, 2018. https://doi.org/10.1155/2018/5967130

Makarewicz, M., Drożdż, I., Tarko, T., \& DudaChodak, A. 2021. The interactions between polyphenols and microorganisms, especially gut microbiota. Antioxidants, 10(2), 1-70. https://doi.org/10.3390/antiox10020188

Maruvada, R., \& McFeeters, R. F. 2009. Evaluation of enzymatic and non-enzymatic softening in low salt cucumber fermentations. International Journal of Food Science and Technology, 44(6), 1108-1117. https://doi.org/10.1111/j.1365-

2621.2009.01925.x
McFeeters, R. F. 2004. Fermentation Microorganisms and Flavor Changes in Fermented Foods. Journal of Food Science, 69(1)

Mubin, M. F., \& Zubaidah, E. 2016. Studi pembuatan kefir nira siwalan (Borassus flabellifer l.) (pengaruh pengenceran nira siwalan dan metode inkubasi). J. Pangan Dan Agroindustri, 4(1), 291-301.

Muhammad, S., \& Elna, K. 2008. LONTAR (Borassus flabellifer). 26-38. https://www.litbang.pertanian.go.id/buku/ba han-bakar-nabati/lontar.pdf

Muscariello, L., Marasco, R., De Felice, M., \& Sacco, M. 2001. The Functional ccpA Gene Is Required for Carbon Catabolite Repression in Lactobacillus plantarum. Applied and Environmental Microbiology, 67(7), 2903-2907. https://doi.org/10.1128/AEM.67.7.29032907.2001

Prayitno, S., Mardiana, N., \& Rochma, N. 2021. Sensory Evaluation Of Wet Noodle Products Added With Moringa Oleifera Flour With Different Concentrations. Kontribusia, 4(2), 450-454.

Roca, M., \& Mínguez-Mosquera, M. I. 2001. Change in the natural ratio between chlorophylls and carotenoids in olive fruit during processing for virgin olive oil. JAOCS, Journal of the American Oil Chemists' Society, 78(2), 133-138. https://doi.org/10.1007/s11746-001-0233-z

Rodríguez, H., Curiel, J. A., Landete, J. M., de las Rivas, B., de Felipe, F. L., Gómez-Cordovés, C., Mancheño, J. M., \& Muñoz, R. 2009. Food phenolics and lactic acid bacteria. International Journal of Food Microbiology, 132(2-3) 3.025 .

Santra, K., Song, A., Petrich, J. W., \& Rasmussen, M. A. 2021. The degradation of chlorophyll pigments in dairy silage: the timeline of anaerobic fermentation. Journal of the 
Science of Food and Agriculture, 101(7), 2863-2868.

https://doi.org/10.1002/jsfa.10917

Silaban, B. M. J. 2017. Optimasi fermentasi produksi etanol dari nira siwalan (Borassus flabellifer) menggunakan mikroorganisme Saccharomyces cerevisiae dan Pichia stipitis dengan Response Surface Methodology. Skripsi, I(1), 134. http://repository.its.ac.id/43605/

Smid, E. J., \& Kleerebezem, M. 2014. Production of aroma compounds in lactic fermentations. Annual Review of Food Science and Technology, 5(1), 313-326. https://doi.org/10.1146/annurev-food030713-092339

Zhao, C. J., Schieber, A., \& Gänzle, M. G. 2016. Formation of taste-active amino acids, derivatives and peptides in food fermentations - A review. Food Research International, 89, 39-47. 